\title{
Advanced Technology Paths to Global Climate Stability: Energy for a Greenhouse Planet
}

\author{
Martin I. Hoffert, ${ }^{1 *}$ Ken Caldeira, ${ }^{3}$ Gregory Benford, ${ }^{4}$ David R. Criswell, ${ }^{5}$ Christopher Green, ${ }^{6}$ Howard Herzog, ${ }^{7}$ Atul K. Jain, ${ }^{8}$

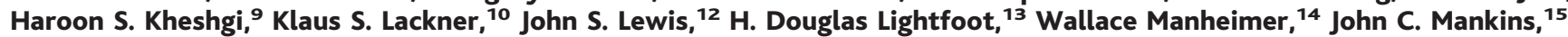 \\ Michael E. Mauel, ${ }^{11}$ L. John Perkins, ${ }^{3}$ Michael E. Schlesinger, ${ }^{8}$ Tyler Volk, ${ }^{2}$ Tom M. L. Wigley ${ }^{16}$
}

\begin{abstract}
Stabilizing the carbon dioxide-induced component of climate change is an energy problem. Establishment of a course toward such stabilization will require the development within the coming decades of primary energy sources that do not emit carbon dioxide to the atmosphere, in addition to efforts to reduce end-use energy demand. Mid-century primary power requirements that are free of carbon dioxide emissions could be several times what we now derive from fossil fuels ( $\sim 10^{13}$ watts), even with improvements in energy efficiency. Here we survey possible future energy sources, evaluated for their capability to supply massive amounts of carbon emission-free energy and for their potential for large-scale commercialization. Possible candidates for primary energy sources include terrestrial solar and wind energy, solar power satellites, biomass, nuclear fission, nuclear fusion, fission-fusion hybrids, and fossil fuels from which carbon has been sequestered. Non-primary power technologies that could contribute to climate stabilization include efficiency improvements, hydrogen production, storage and transport, superconducting global electric grids, and geoengineering. All of these approaches currently have severe deficiencies that limit their ability to stabilize global climate. We conclude that a broad range of intensive research and development is urgently needed to produce technological options that can allow both climate stabilization and economic development.
\end{abstract}

$\mathbf{M}$ ore than a century ago, Arrhenius put forth the idea that $\mathrm{CO}_{2}$ from fossil fuel burning could raise the infrared opacity of the atmosphere enough to warm Earth (1). In the 20th century, the human population quadrupled and primary power consumption increased 16-fold (2). The fossil fuel greenhouse theory has become more credible as observations accumulate and as we better understand the links between

${ }^{1}$ Department of Physics, ${ }^{2}$ Department of Biology, New York University, New York, NY 10003, USA. ${ }^{3}$ Lawrence Livermore National Laboratory, Livermore, CA 94550, USA. ${ }^{4}$ Department of Physics and Astronomy, University of California, Irvine, CA 92697, USA. ${ }^{5}$ Institute of Space Systems Operations, University of Houston, Houston, TX 77204, USA. ${ }^{6}$ Department of Economics, McGill University, Montreal, Quebec H3A 2T7, Canada. ${ }^{7}$ MIT Laboratory for Energy and the Environment, Cambridge, MA 02139, USA. ${ }^{8}$ Department of Atmospheric Sciences, University of Illinois at Urbana-Champaign, Urbana, IL 61801, USA. ${ }^{9}$ ExxonMobil Research and Engineering Company, Annandale, NJ 08801, USA. ${ }^{10}$ Department of Earth and Environmental Engineering, ${ }^{11}$ Department of Applied Physics and Applied Mathematics, Columbia University, New York, NY 10027, USA. ${ }^{12}$ Lunar and Planetary Laboratory, University of Arizona, Tucson, AZ 85721, USA. ${ }^{13}$ Centre for Climate and Global Change Research, McGill University, Montreal, Quebec H3A 2K6, Canada. ${ }^{14}$ Plasma Physics Division, Naval Research Laboratory, Washington, DC 20375, USA. ${ }^{15}$ NASA Headquarters, Washington, DC 20546, USA. ${ }^{16} \mathrm{Na}-$ tional Center for Atmospheric Research, Boulder, $\mathrm{CO}$ 80307, USA.

*To whom correspondence should be addressed. Email: marty.hoffert@nyu.edu fossil fuel burning, climate change, and environmental impacts (3). Atmospheric $\mathrm{CO}_{2}$ has increased from $\sim 275$ to $\sim 370$ parts per million (ppm). Unchecked, it will pass 550 ppm this century. Climate models and paleoclimate data indicate that $550 \mathrm{ppm}$, if sustained, could eventually produce global warming comparable in magnitude but opposite in sign to the global cooling of the last Ice Age (4)

The United Nations Framework Convention on Climate Change aims to stabilize greenhouse gas concentrations at levels that avoid "dangerous anthropogenic interference with the climate system (5)." Atmospheric $\mathrm{CO}_{2}$ stabilization targets as low as $450 \mathrm{ppm}$ could be needed to forestall coral reef bleaching, thermohaline circulation shutdown, and sea level rise from disintegration of the West Antarctic Ice Sheet (6). Wigley and colleagues developed emission scenarios to stabilize atmospheric $\mathrm{CO}_{2}$ at 350, 450, 550, 650, or $750 \mathrm{ppm}$ (7). They minimized early emission controls by initially following a business-as-usual scenario that combines economic growth of 2 to $3 \%$ year $^{-1}$ with a sustained decline of $1 \%$ year $^{-1}$ in energy intensity (energy use per gross domestic product). Much larger cuts than those called for in the Kyoto Protocol are needed later, because the levels at which $\mathrm{CO}_{2}$ stabilize depend approximately on total emissions. Targets of cutting to $450 \mathrm{ppm}$, and certainly $350 \mathrm{ppm}$, could require Herculean effort. Even holding at $550 \mathrm{ppm}$ is a major challenge.

Primary power consumption today is $\sim 12$ TW, of which $85 \%$ is fossil-fueled. Stabilization at 550, 450, and $350 \mathrm{ppm} \mathrm{CO}_{2}$ by Wigley et al. scenarios require emission-free power by mid-century of 15,25 , and $>30 \mathrm{TW}$, respectively (8). Attaining this goal is not easy. $\mathrm{CO}_{2}$ is a combustion product vital to how civilization is powered; it cannot be regulated away. $\mathrm{CO}_{2}$ stabilization could prevent developing nations from basing their energy supply on fossil fuels (9). Hansen et $a l$. call for reductions in methane and black soot, which also cause warming (10). Such reductions are desirable but do not address fossil fuel greenhouse warming. The Kyoto Protocol calls for greenhouse gas emission reductions by developed nations that are 5\% below 1990 levels by 2008 to 2012. Paradoxically, Kyoto is too weak and too strong: Too strong because its initial cuts are perceived as an economic burden by some (the United States withdrew for this stated reason); too weak because much greater emission reductions will be needed, and we lack the technology to make them.

Arguably, the most effective way to reduce $\mathrm{CO}_{2}$ emissions with economic growth and equity is to develop revolutionary changes in the technology of energy production, distribution, storage, and conversion (8). The need to intensify research on such technologies now is by no means universally appreciated. Present U.S. policy emphasizes domestic oil production, not energy technology research (11). Misperceptions of technological readiness also appear in the latest "Summary for Policymakers" by the "Mitigation" Working Group of the Intergovernmental Panel on Climate Change (IPCC): “. . known technological options could achieve a broad range of atmospheric $\mathrm{CO}_{2}$ stabilization levels, such as $550 \mathrm{ppm}, 450 \mathrm{ppm}$ or below over the next 100 years or more. ... Known technological options refer to technologies that exist in operation or pilot plant stage today. It does not include any new technologies that will require drastic technological breakthroughs. ..." (12)

This statement does not recognize the $\mathrm{CO}_{2}$ emission-free power requirements implied by the IPCC's own reports $(3,8)$ and is not supported by our assessment. Energy 


\section{SCIENCE'S COMPASS}

sources that can produce 100 to $300 \%$ of present world power consumption without greenhouse emissions do not exist operationally or as pilot plants.

Can we produce enough emission-free power in time? Here we assess the potential of a broad range of technologies aimed at meeting this goal.

\section{Improving Efficiency}

Efficiency is the ratio of usable energy output to energy input. Primary energy in metastable chemical and nuclear bonds includes fossil fuels, fission fuels, and fusion fuels. "Renewables" are primary energy in natural fluxes (solar photons, wind, water, and heat flows). Energy conversion always involves dissipative losses, losses that in many cases engineers have already expended considerable ef- fort to reduce. Opportunities still exist to improve efficiency in power generation and end-use sectors: transportation, manufacturing, electricity, and (indoor) climate conditioning (13).

The efficiencies of mature technologies are well characterized $(14,15)$. Most efficient are large electric generators (98 to $99 \%$ efficient) and motors (90 to 97\%). These are followed by rotating heat engines that are limited by the second law of thermodynamics: gas and steam turbines ( 35 to $50 \%$ ) and diesel (30 to $35 \%)$ and internal combustion (15 to $25 \%$ ) engines. Electrolyte and electrode materials and catalysts limit electrochemical fuel cells (50 to 55\% now; $70 \%$ eventually). Fuel cells may replace heat engines but will likely run on hydrogen. A seamless transition would use $\mathrm{H}_{2}$ extracted

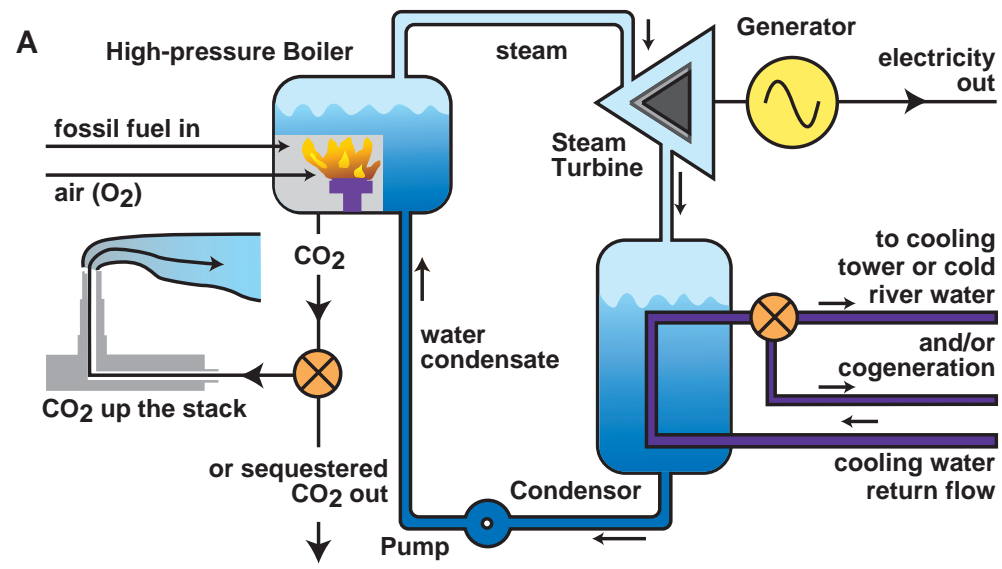

\begin{tabular}{|c|c|c|c|c|c|c|}
\hline \multirow[t]{4}{*}{ B } & & $\begin{array}{c}\text { Energy content } \\
\text { [TW-yr] }\end{array}$ & $\begin{array}{c}\text { Carbon content } \\
\text { [GTC] }\end{array}$ & $\begin{array}{c}\left(E_{\text {fuel }} / \mathrm{C}\right) \\
{[\mathrm{TW}-\mathrm{yr} / \mathrm{GtC}]}\end{array}$ & $\begin{array}{c}(\mathrm{E} / \mathrm{C}) \\
{[\mathrm{TW}-\mathrm{yr} / \mathrm{GtC}]}\end{array}$ & $\begin{array}{l}\text { Sequestration } \\
\text { rate }[\mathrm{GtC} / \mathrm{yr}]\end{array}$ \\
\hline & & 1200 & 570 & 2.1 & $1.9-1.6$ & $5-6$ \\
\hline & \begin{tabular}{l|c|} 
B & $\begin{array}{c}\text { Fossil } \\
\text { fuel }\end{array}$ \\
\cline { 2 - 3 } & Gas \\
Oil
\end{tabular} & 1200 & 750 & 1.6 & $1.4-1.2$ & $7-8$ \\
\hline & Coal & 4800 & 3690 & 1.3 & $1.2-1.0$ & $9-10$ \\
\hline \multicolumn{7}{|c|}{$10 \mathrm{TW} \mathrm{CO} 2^{- \text {emission-free from fossil fuels }}$} \\
\hline
\end{tabular}

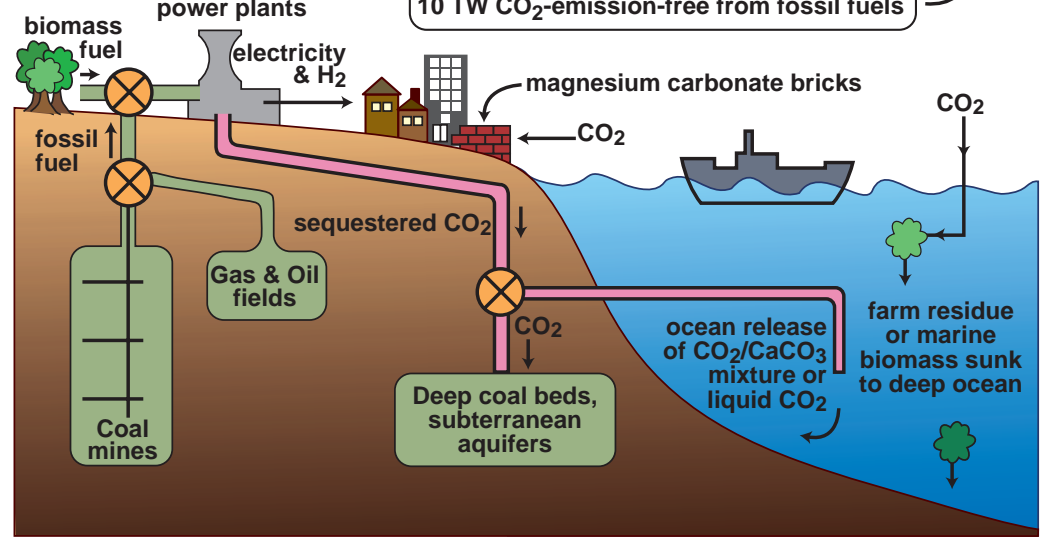

Fig. 1. (A) Fossil fuel electricity from steam turbine cycles. (B) Collecting $\mathrm{CO}_{2}$ from central plants and air capture, followed by subterranean, ocean, and/or solid carbonate sequestration, could foster emission-free electricity and hydrogen production, but huge processing and sequestration rates are needed ( 5 to $10 \mathrm{GtC}$ year ${ }^{-1}$ to produce $10 \mathrm{TW}$ emission-free assuming energy penalties of 10 to $25 \%)$.

from gasoline or methanol in reformers ( 75 to $80 \%$ ). Renewable energy converters include photovoltaic (PV) cells (commercial arrays, about 15 to $20 \%$; theoretical peak for single bandgap crystalline cells, $\approx 24 \%$; higher for multiband cells, lower for more cost-effective amorphous thin films) and wind turbines (commercial units, about 30 to $40 \%$; theoretical "Betz limit," $\approx 59 \%$ ). High-pressure sodium vapor (15 to $20 \%$ ), fluorescent (10 to $12 \%$ ), and incandescent ( 2 to $5 \%$ ) illumination generate more heat than light. Photosynthesis has a very low sunlight-to-chemical energy efficiency, limited by chlorophyll absorption bands (most productive ecosystems are about 1 to $2 \%$ efficient; theoretical peak independent of cell or ecosystem is $\approx 8 \%$ ).

How much can energy efficiency improve? In a given technology class, efficiency normally starts low, grows for decades to centuries, and levels off at some fraction of its theoretical peak (16). It took 300 years to develop fuel cells from $1 \%$-efficient steam engines. The earliest gas turbines could barely turn their compressors. The development of fusion could be similar: The best experiments are close to balancing power to ignite the plasma; power is carried off by fusiongenerated neutrons, but no net power output has occurred yet. Fossil and nuclear fuels are much closer to their limits (Figs. 1A and 4A). Steam-cycle efficiencies (39 to $50 \%$, including combined cycles and cogeneration) and overall primary energy-to-electricity efficiency (30 to $36 \%$, including transmission losses) yield the nominal thermal-to-electric power conversion: $3 \mathrm{~kW}$ (thermal) $\approx 1 \mathrm{~kW}_{\mathrm{e}}$ (electrical). Impressive reductions in waste heat have been accomplished with compact fluorescents, low emissivity windows, and cogeneration (17). More efficient automotive power conversion is possible $(18,19)$. Emissions depend on vehicle mass, driving patterns, and aerodynamic drag, as well as well-to-wheels efficiency [(torque $\times$ angular velocity at wheels)/(fossil fuel power in)]. Power trains are typically 18 to $23 \%$ efficient for internal combustion (IC), 21 to $27 \%$ for battery-electric (35 to $40 \%$, central power plant; 80 to $85 \%$, charge-discharge cycles; 80 to $85 \%$, motor), 30 to $35 \%$ for IC-electric hybrid (higher efficiency from electric power recovery of otherwise lost mechanical energy), and 30 to $37 \%$ for fuel cell-electric ( 75 to $80 \%$, reformer; 50 to $55 \%$, fuel cell; 80 to $85 \%$, motor).

Lifestyles also affect emissions. Ultra fuel-efficient cars are available today that can travel up to $29 \mathrm{~km} \mathrm{liter}^{-1}$ [68 miles per gallon (mpg) U.S. Environmental Protection Agency highway driving cycle (EPA hwy)]. But consumer demand for sport utility vehicles (SUVs) has driven the fuel economy of the U.S. car and light truck fleet to a 21-year low of $8.5 \mathrm{~km} \mathrm{liter}^{-1}$ (20 mpg EPA hwy) 


\section{SCIENCE'S COMPASS}

(19). Even with SUVs, doubling (or more) efficiency is quite feasible. Unfortunately, the effects of such efficiency could be overwhelmed if China and India follow the U.S. path from bicycles and mass transit to cars. (Asia already accounts for $>80 \%$ of petroleum consumption growth.) As a result, carbon-neutral fuels or $\mathrm{CO}_{2}$ "air capture" may be the best alternatives to develop.

Reducing the amount of carbon emitted per unit of primary energy is called decarbonization. The long-term trend has been from coal to oil to gas, with each fuel emitting progressively less $\mathrm{CO}_{2}$ per joule of heat (20). Continuation of the trend would lead to use of $\mathrm{H}_{2}$, a carbon-neutral fuel, but $\mathrm{H}_{2}$ does not exist in geological reservoirs. Processes requiring energy are needed for its synthesis. The energy can come from fossil fuel feedstocks. $\mathrm{H}_{2}$ is produced today by steamreforming natural gas $\left(2 \mathrm{H}_{2} \mathrm{O}+\mathrm{CH}_{4} \rightarrow 4 \mathrm{H}_{2}+\right.$ $\mathrm{CO}_{2}$ ). Energy can be transferred to $\mathrm{H}_{2}$ with an efficiency of about $72 \%$ from gas, $76 \%$ from oil, and 55 to $60 \%$ from coal (21). Per unit of heat generated, more $\mathrm{CO}_{2}$ is produced by making $\mathrm{H}_{2}$ from fossil fuel than by burning the fossil fuel directly. Emission-free $\mathrm{H}_{2}$ manufactured by water electrolysis that is powered by renewable or nuclear sources is not yet cost effective.

Thus, the decarbonization of fuels alone will not mitigate global warming. The underlying problem is providing 10 to $30 \mathrm{TW}$ emission-free in 50 years. Continuing the trend to lower carbon fuels requires disposing of excess carbon because the trend opposes the relative abundance of fossil resourceshigh-carbon coal being most abundant, followed by oil and gas $(22,23)$. One vision of "clean" coal incorporates $\mathrm{CO}_{2}$ capture and sequestration: Coal and/or biomass and waste materials are gasified in an oxygen-blown gasifier, and the product is cleaned of sulfur and reacted with steam to form $\mathrm{H}_{2}$ and $\mathrm{CO}_{2}$. After heat extraction, the $\mathrm{CO}_{2}$ is sequestered and the $\mathrm{H}_{2}$ used for transportation or electricity generation (24). Decarbonization is thus intimately linked to sequestration (25). Sequestration reservoirs include oceans, trees, soils, depleted natural gas and oil fields, deep saline aquifers, coal seams, and solid mineral carbonates (Fig. 1B). The main advantage of sequestration is its compatibility with existing fossil fuel infrastructures, including $\mathrm{CO}_{2}$ injections for enhanced recovery from existing oil and gas fields and capture of $\mathrm{CO}_{2}$ from power plant flue gases.

Recovery of fossil fuel $\mathrm{CO}_{2}$ emitted from decentralized sources (like cars) may be needed. The simplest air capture is forestation. Tree and soil sequestration does not require combustion product separation or more fuel, but the capacity to absorb $\mathrm{CO}_{2}$ is limited. Uptake occurs during growth of or-

\section{Decarbonization and Sequestration}

ganic matter $\left(\mathrm{CH}_{2} \mathrm{O}\right)$, when the net photosynthesis-respiration reaction is to the right: $h v$ $+\mathrm{CO}_{2}+\mathrm{H}_{2} \mathrm{O} \rightarrow \mathrm{CH}_{2} \mathrm{O}+\mathrm{O}_{2}$. Historical $\mathrm{CO}_{2}$ data and models imply a temperate forest carbon sink today of 1 to 3 billion tons of carbon (GtC) year ${ }^{-1}$ (3), but some models show forests reversing from sinks to sources later this century as global warming increases soil respiration (26). The exchange time of $\mathrm{CO}_{2}$ with trees is $\sim 7$ years. Turnover of iron fertilization-enhanced plankton uptake (27) can be similarly fast if organic detritus oxidizes near the surface. Biological sequestration approaches to longer term storage include sealing undecayed trees underground (28) and sinking agricultural residues to the deep ocean (29). Air capture by aqueous calcium hydroxide $\left[\mathrm{Ca}(\mathrm{OH})_{2}\right]$ in shallow pools, with $\mathrm{CO}_{2}$ recovery by heating $\mathrm{CaCO}_{3}$ in a retort to produce $\mathrm{CaO}$ and $\mathrm{CO}_{2}$, has also been proposed (30). This reaction (calcination) is a key step in making cement from limestone, but breaking the $\mathrm{Ca}-\mathrm{CO}_{2}$ bond requires substantial energy.

Also being explored is longer term $\mathrm{CO}_{2}$ sequestration in the deep sea (31). For a given emission scenario, ocean injections can sub- stantially decrease peak atmospheric $\mathrm{CO}_{2}$ levels, although all cases eventually diffuse some $\mathrm{CO}_{2}$ back to the atmosphere (32). Backdiffusion and $\mathrm{pH}$ impacts of ocean $\mathrm{CO}_{2}$ disposal could be diminished by accelerating carbonate mineral weathering that would otherwise slowly neutralize the oceanic acidity produced by fossil fuel $\mathrm{CO}_{2}(33,34)$. A with the mineral serpentine to sequester carbon as a solid in magnesium carbonate "bricks" by vastly accelerating silicate rock weathering reactions, which remove atmospheric $\mathrm{CO}_{2}$ over geologic time scales (35). Thus, carbon sequestration could be a valuable bridge to renewable and/or nuclear energy. However, if other emission-free primary power sources of 10 to $30 \mathrm{TW}$ are unavailable by mid-century, then enormous sequestration rates could be needed to stabilize atmospheric $\mathrm{CO}_{2}$ (Fig. 1B). Substantial research investments are needed now to make this technology available in time.

\section{Renewables}

Renewable energy technologies include biomass, solar thermal and photovoltaic, wind, far-reaching removal scheme is reacting $\mathrm{CO}_{2}$

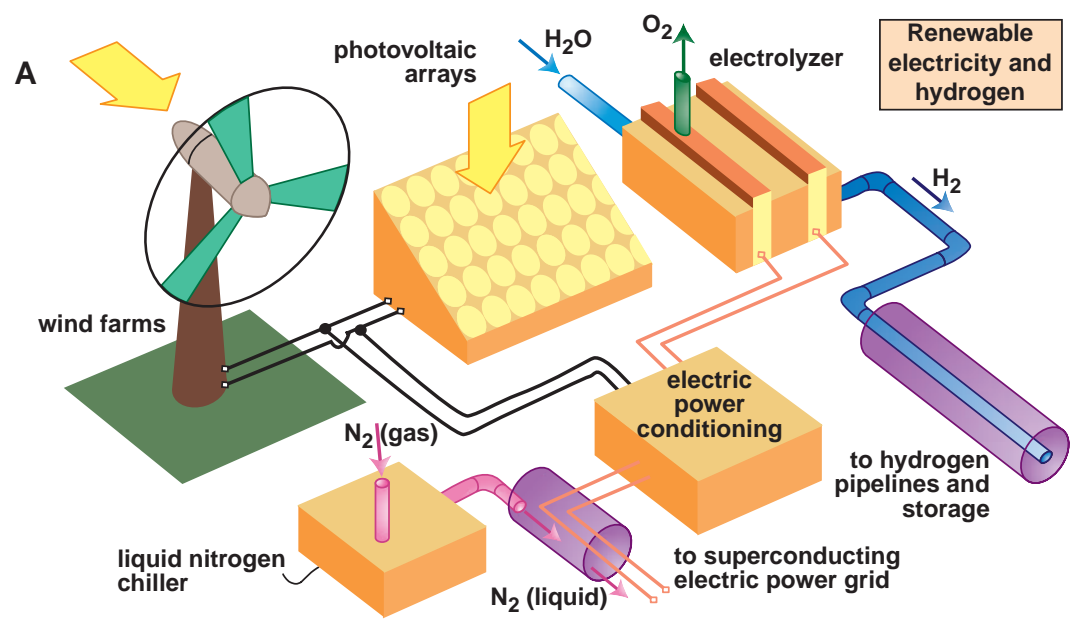

B

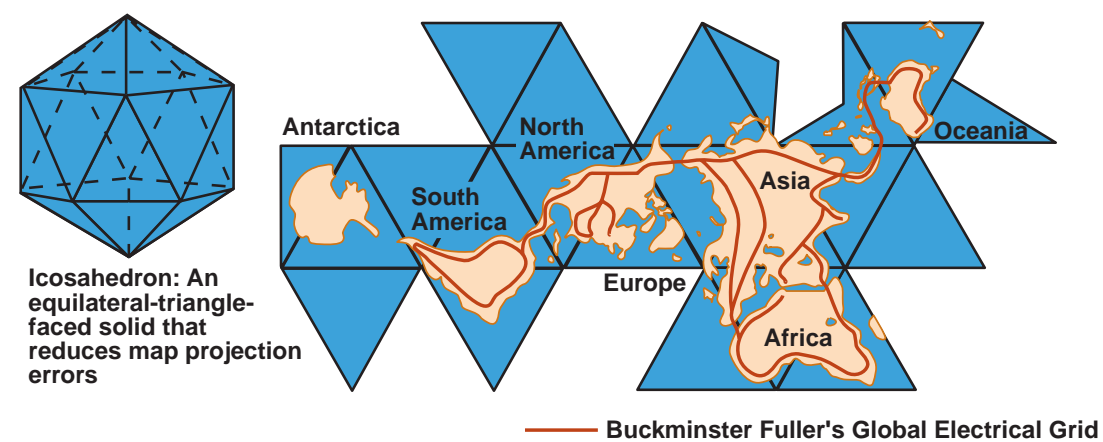

Fig. 2. (A) Mass-produced widely distributed PV arrays and wind turbines making electrolytic $\mathrm{H}_{2}$ or electricity may eventually generate 10 to 30 TW emission-free. (B) The global grid proposed by R. Buckminster Fuller with modern computerized load management and high-temperature superconducting (HTS) cables could transmit electricity from day to night locations and foster low-loss distribution from remote, episodic, or dangerous power sources. (The resistivity of HTS wires vanishes below the $77 \mathrm{~K}$ boiling point of nitrogen available from air.) 


\section{SCIENCE'S COMPASS}

hydropower, ocean thermal, geothermal, and tidal (36). With the exception of firewood and hydroelectricity (close to saturation), these are collectively $<1 \%$ of global power. All renewables suffer from low areal power densities. Biomass plantations can produce carbon-neutral fuels for power plants or transportation, but photosynthesis has too low a power density $\left(\sim 0.6 \mathrm{~W} \mathrm{~m}^{-2}\right)$ for biofuels to contribute significantly to climate stabilization $(14,37)$. (10 TW from biomass requires $>10 \%$ of Earth's land surface, comparable to all of human agriculture.) PV and wind energy $\left(\sim 15 \mathrm{~W}_{\mathrm{e}} \mathrm{m}^{-2}\right)$ need less land, but other materials can be limiting. For solar energy, U.S. energy consumption may require a PV array covering a square $\sim 160 \mathrm{~km}$ on each side $\left(26,000 \mathrm{~km}^{2}\right)(38)$. The electrical equivalent of $10 \mathrm{TW}\left(3.3 \mathrm{TW}_{\mathrm{e}}\right)$ requires a surface array $\sim 470 \mathrm{~km}$ on a side $(220,000$ $\mathrm{km}^{2}$ ). However, all the PV cells shipped from 1982 to 1998 would only cover $\sim 3 \mathrm{~km}^{2}$ (39). A massive (but not insurmountable) scale-up is required to get 10 to $30 \mathrm{TW}$ equivalent.

More cost-effective PV panels and wind turbines are expected as mass production drives economies of scale. But renewables are intermittent dispersed sources unsuited to baseload without transmission, storage, and power conditioning. Wind power is often available only from remote or offshore locations. Meeting local demand with PV arrays today requires pumped-storage or battery-electric backup systems of comparable or greater capacity (40).

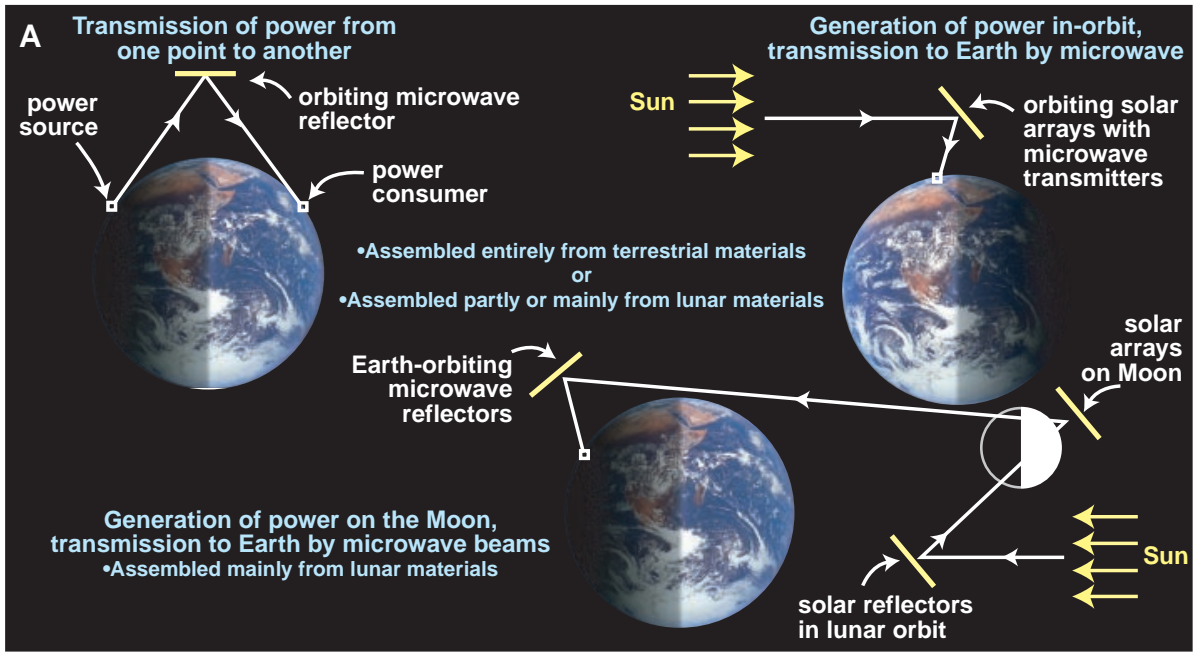

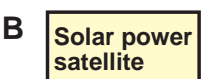
satellite

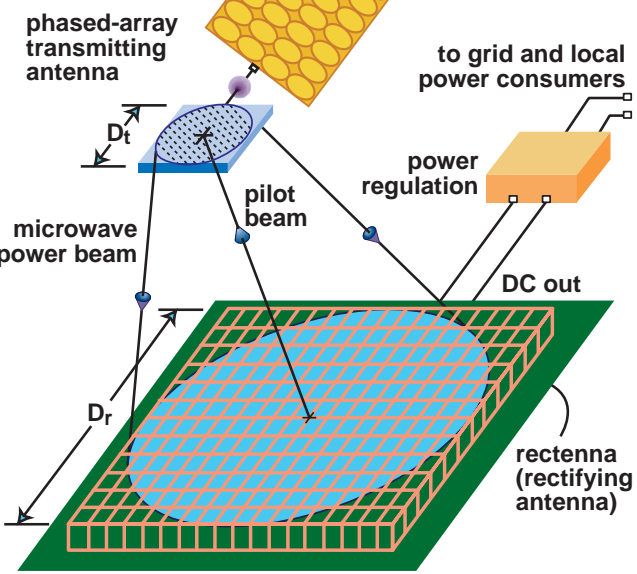

sun-tracking PV arrays in orbit

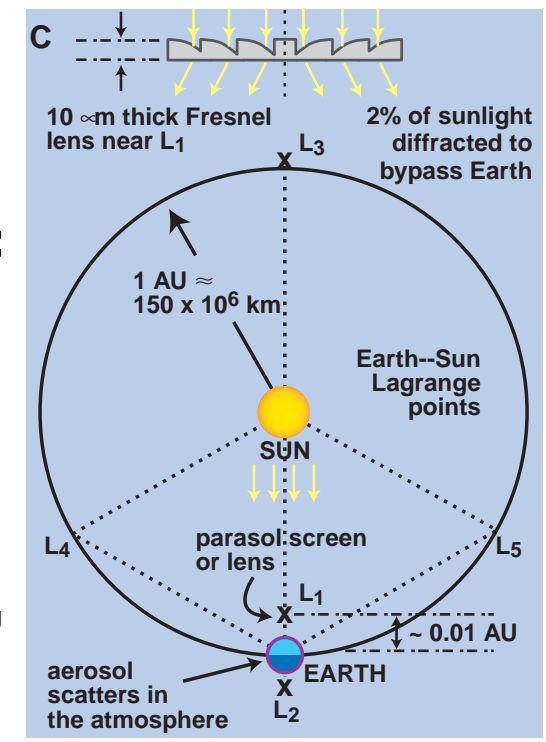

the atmospher
Fig. 3. Capturing and controlling sun power in space. (A) The power relay satellite, solar power satellite (SPS), and lunar power system all exploit unique attributes of space (high solar flux, lines of sight, lunar materials, shallow gravitational potential well of the Moon). (B) An SPS in a low Earth orbit can be smaller and cheaper than one in geostationary orbit because it does not spread its beam as much; but it does not appear fixed in the sky and has a shorter duty cycle (the fraction of time power is received at a given surface site). (C) Space-based geoengineering. The Lagrange interior point $L_{1}$ provides an opportunity for radiative forcing to oppose global warming. A $2000-\mathrm{km}$-diameter parasol near $\mathrm{L}_{1}$ could deflect $2 \%$ of incident sunlight, as could aerosols with engineered optical properties injected in the stratosphere.
"Balance-of-system" infrastructures could evolve from natural gas fuel cells if reformer $\mathrm{H}_{2}$ is replaced by $\mathrm{H}_{2}$ from PV or wind electrolysis (Fig. 2A). Reversible electrolyzer and fuel cells offer higher current (and power) per electrode area than batteries, $\sim 20 \mathrm{~kW}_{\mathrm{e}} \mathrm{m}^{-2}$ for proton exchange membrane (PEM) cells (21). PEM cells need platinum catalysts, $\geq 5 \times 10^{-3} \mathrm{~kg} \mathrm{Pt}$ $\mathrm{m}^{-2}$ (41) (a 10-TW hydrogen flow rate could require 30 times as much as today's annual world platinum production). Advanced electrical grids would also foster renewables. Even if $\mathrm{PV}$ and wind turbine manufacturing rates increased as required, existing grids could not manage the loads. Present hub-and-spoke networks were designed for central power plants, ones that are close to users. Such networks need to be reengineered. Spanning the world electrically evokes Buckminster Fuller's global grid (Fig. 2B). Even before the discovery of hightemperature superconductivity (42), Fuller envisioned electricity wheeled between day and night hemispheres and pole-to-pole (43). Worldwide deregulation and the free trade of electricity could have buyers and sellers establishing a supply-demand equilibrium to yield a worldwide market price for grid-provided electricity.

Space solar power (SSP) (Fig. 3, A and B) exploits the unique attributes of space to power Earth $(44,45)$. Solar flux is $\sim 8$ times higher in space than the long-term surface average on spinning, cloudy Earth. If theoretical microwave transmission efficiencies (50 to $60 \%$ ) can be realized, 75 to $100 \mathrm{~W}_{\mathrm{e}}$ could be available at Earth's surface per $\mathrm{m}^{2}$ of PV array in space, $\leq 1 / 4$ the area of surface PV arrays of comparable power. In the 1970s, the National Aeronautics and Space Administration (NASA) and the U.S. Department of Energy (DOE) studied an SSP design with a $\mathrm{PV}$ array the size of Manhattan in geostationary orbit [(GEO) $35,800 \mathrm{~km}$ above the equator] that beamed power to a $10-\mathrm{km}$ by $13-\mathrm{km}$ surface rectenna with $5 \mathrm{GW}_{\mathrm{e}}$ output. [10 TW equivalent $\left(3.3 \mathrm{TW}_{\mathrm{e}}\right)$ requires $660 \mathrm{SSP}$ units.] Other architectures, smaller satellites, and newer technologies were explored in the NASA "Fresh Look Study" (46). Alternative locations are 200- to $10,000-\mathrm{km}$ altitude satellite constellations (47), the Moon $(48,49)$, and the Earth-Sun $\mathrm{L}_{2}$ Lagrange exterior point [one of five libration points corotating with the Earth-Sun system (Fig. 3C)] (50). Potentially important for $\mathrm{CO}_{2}$ emission reduction is a demonstration proposed by Japan's Institute of Space and Aeronautical Science to beam solar energy to developing nations a few degrees from the equator from a satellite in low equatorial orbit (51). Papua New Guinea, Indonesia, Ecuador, and Colombia on the Pacific Rim, and Malaysia, Brazil, Tanzania, and the Maldives have agreed to participate in such experiments (52). A major challenge is reducing or externalizing high launch 


\section{SCIENCE'S COMPASS}

costs. With adequate research investments, SSP could perhaps be demonstrated in 15 to 20 years and deliver electricity to global markets by the latter half of the century $(53,54)$.

\section{Fission and Fusion}

Nuclear electricity today is fueled by ${ }^{235} \mathrm{U}$. Bombarding natural $U$ with neutrons of a few $\mathrm{eV}$ splits the nucleus, releasing a few hundred million $\mathrm{eV}\left({ }^{235} \mathrm{U}+\mathrm{n} \rightarrow\right.$ fission products + $2.43 \mathrm{n}+202 \mathrm{MeV})(55)$. The ${ }^{235} \mathrm{U}$ isotope, $0.72 \%$ of natural $U$, is often enriched to 2 to $3 \%$ to make reactor fuel rods. The existing $\sim 500$ nuclear power plants are variants of ${ }^{235} \mathrm{U}$ thermal reactors $(56,57)$ : the light water reactor [(LWR) in both pressurized and boiling versions]; heavy water (CANDU) reactor; graphite-moderated, water-cooled (RBMK) reactors, like Chernobyl; and gas-cooled graphite reactors. LWRs ( $85 \%$ of today's reactors) are based largely on Hyman Rickover's water-cooled submarine reactor (58). Loss-of-coolant accidents [Three Mile Island (TMI) and Chernobyl] may be avoidable in the future with "passively safe" reactors (Fig. 4A). Available reactor technology can provide $\mathrm{CO}_{2}$ emission-free electric power, though it poses well-known problems of waste disposal and weapons proliferation.

The main problem with fission for climate stabilization is fuel. Sailor et al. (58) propose a scenario with ${ }^{235} \mathrm{U}$ reactors producing $\sim 10$ TW by 2050 . How long before such reactors run out of fuel? Current estimates of $U$ in proven reserves and (ultimately recoverable) resources are 3.4 and 17 million metric tons, respectively (22) [Ores with 500 to 2000 parts per million by weight (ppmw) $U$ are considered recoverable (59)]. This represents 60 to $300 \mathrm{TW}$-year of primary energy (60). At $10 \mathrm{TW}$, this would only last 6 to 30 years - hardly a basis for energy policy. Recoverable U may be underestimated. Still, with 30- to 40-year reactor lifetimes, it would be imprudent (at best) to initiate fission scaleup without knowing whether there is enough fuel. What about the seas? Japanese researchers have harvested dissolved U with organic adsorbents from flowing seawater (61). Oceans have $3.2 \times 10^{-6} \mathrm{~kg}$ dissolved $\mathrm{U} \mathrm{m}^{-3}$ (62) - $\mathrm{a}^{235} \mathrm{U}$ energy density of $1.8 \mathrm{MJ} \mathrm{m}^{-3}$. Multiplying by the oceans' huge volume $\left(1.37 \times 10^{18} \mathrm{~m}^{3}\right)$ gives 4.4 billion metric tons $\mathrm{U}$ and $80,000 \mathrm{TW}$-year in ${ }^{235} \mathrm{U}$. Runoff and outflow to the sea from all the world's rivers is $1.2 \times 10^{6} \mathrm{~m}^{3} \mathrm{~s}^{-1}(63)$. Even with $100 \%$ ${ }^{235} \mathrm{U}$ extraction, the flow rate needed to make reactor fuel at the $10 \mathrm{TW}$ rate is five times as much as this outflow (64). Getting $10 \mathrm{TW}$ primary power from ${ }^{235} \mathrm{U}$ in crustal ores or seawater extraction may not be impossible, but it would be a big stretch.

Despite enormous hurdles, the most promising long-term nuclear power source is still fusion (65). Steady progress has been made toward "breakeven" with tokamak (a toroidal near-vacuum chamber) magnetic confinement $[\mathrm{Q} \equiv$ (neutron or charged particle energy out)/(energy input to heat plasma) $=1$ ] (Fig. 4B). The focus has been on the deuterium-tritium (D-T) reaction $(\rightarrow$ $\left.{ }^{4} \mathrm{He}+\mathrm{n}+17.7 \mathrm{MeV}\right)$. Breakeven requires that the "plasma triple product" satisfy the Lawson criteria: $\mathrm{n} \times \tau \times k T \approx 1 \times 10^{21} \mathrm{~m}^{-3}$ $\mathrm{s} \mathrm{keV}$ for the D-T reaction, where $\mathrm{n}$ is number density; $\tau$, confinement time; $T$, temperature; and $k$, Boltzmann's constant $(66,67)$. Best results from Princeton (Tokamak Fusion Test Reactor) and Europe (Joint European Torus) are within a factor of two (68). Higher Qs are needed for power reactors: Neutrons penetrating the "first wall" would be absorbed by molten lithium, and excess heat would be transferred to turbogenerators. Tritium (12.3year half-life) would also be bred in the lithium blanket $\left(\mathrm{n}+{ }^{6} \mathrm{Li} \rightarrow{ }^{4} \mathrm{He}+\mathrm{T}+4.8\right.$ $\mathrm{MeV}) . \mathrm{D}$ in the sea is virtually unlimited whether utilized in the D-T reaction or the harder-to-ignite D-D reactions $\left(\rightarrow{ }^{3} \mathrm{He}+\right.$ $\mathrm{n}+3.2 \mathrm{MeV}$ and $\rightarrow \mathrm{T}+\mathrm{p}+4.0 \mathrm{MeV})$. If $\mathrm{D}-\mathrm{T}$ reactors were operational, lithium bred to $\mathrm{T}$ could generate $16,000 \mathrm{TW}$-year (69), twice the thermal energy in fossil fuels. The D- ${ }^{3} \mathrm{He}$ reaction $\left(\rightarrow{ }^{4} \mathrm{He}+\mathrm{p}+18.3 \mathrm{MeV}\right)$ is of interest because it yields charged particles directly convertible to electricity (70). Studies of $\mathrm{D}-{ }^{3} \mathrm{He}$ and $\mathrm{D}-\mathrm{D}$ burning in inertial confinement fusion targets suggest that central D-T ignitors can spark these reactions.
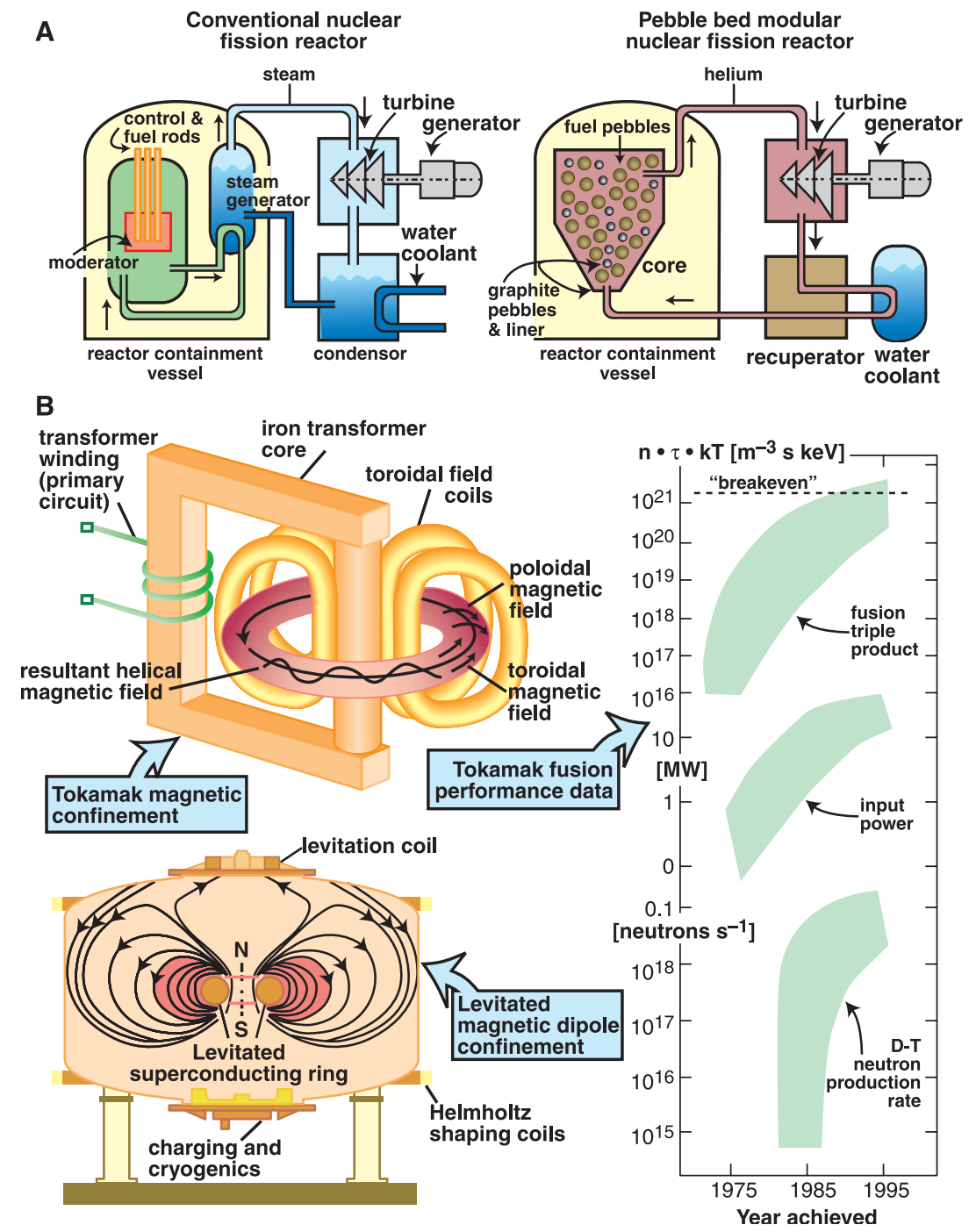

Fig. 4. (A) The conventional LWR employs water as both coolant and working fluid (left). The helium-cooled, graphite-moderated, pebble-bed, modular nuclear fission reactor is theoretically immune to loss-of-coolant meltdowns like TMI and Chernobyl (right). (B) The most successful path to fusion has been confining a D-T plasma (in purple) with complex magnetic fields in a tokamak. Breakeven occurs when the plasma triple product (number density $\times$ confinement time $\times$ temperature) attains a critical value. Recent tokamak performance improvements were capped by near-breakeven [data sources in (68)]. Experimental work on advanced fusion fuel cycles and simpler magnetic confinement schemes like the levitated dipole experiment (LDX) shown are recommended. 


\section{SCIENCE'S COMPASS}

Ignition of D-T-fueled inertial targets and associated energy gains of $\mathrm{Q} \geq 10$ may be realized in the National Ignition Facility within the next decade. Experiments are under way to test dipole confinement by a superconducting magnet levitated in a vacuum chamber (71), a possible $\mathrm{D}-{ }^{3} \mathrm{He}$ reactor prototype. Rare on Earth, ${ }^{3} \mathrm{He}$ may someday be cost-effective to mine from the Moon (72). It is even more abundant in gas-giant planetary atmospheres (73). Seawater D and outer planet ${ }^{3} \mathrm{He}$ could power civilization longer than any source other than the Sun.

How close, really, are we to using fusion? Devices with a larger size or a larger magnetic field strength are required for net power generation. Until recently, the fusion community was promoting the International Thermonuclear Experimental Reactor (ITER) to test engineering feasibility. Enthusiasm for ITER waned because of the uncertainty in raising the nearly $\$ 10$ billion needed for construction. The U.S. halted ITER sponsorship in 1998, but there is renewed interest among U.S. fusion scientists to build a smaller-sized, higher-field, nonsuperconducting experiment or to rejoin participation in a half-sized, redesigned ITER physics experiment. A "burning plasma experiment" could produce net fusion power at an affordable scale and could allow detailed observation of confined plasma during self-heating by hot alpha particles. The Fusion Energy Sciences Act of 2001 calls on DOE to "develop a plan for United States construction of a magnetic fusion burning plasma experiment for the purpose of accelerating scientific understanding of fusion plasmas (74)." This experiment is a critical step to the realization of practical fusion energy. Demonstrating net electric power production from a self-sustaining fusion reactor would be a breakthrough of overwhelming importance but cannot be relied on to aid $\mathrm{CO}_{2}$ stabilization by mid-century.

The conclusion from our ${ }^{235} \mathrm{U}$ fuel analysis is that breeder reactors are needed for fission to significantly displace $\mathrm{CO}_{2}$ emissions by 2050 . Innovative breeder technologies include fusion-fission and acceleratorfission hybrids. Fissionable ${ }^{239} \mathrm{Pu}$ and/or ${ }^{233} \mathrm{U}$ can be made from ${ }^{238} \mathrm{U}$ and ${ }^{232} \mathrm{Th}$ (75). Commercial breeding is illegal today in the United States because of concerns over waste and proliferation (France, Germany, and Japan have also abandoned their breeding programs). Breeding could be more acceptable with safer fuel cycles and transmutation of high-level wastes to benign products (76). Th is the more desirable feedstock: It is three times more abundant than $U$ and ${ }^{233} U$ is harder to separate and divert to weapons than plutonium. One idea to speed up breeding of ${ }^{233} \mathrm{U}$ is to use tokamak-derived fusion-fission hybrids $(68,77)$. D-T fusion yields a 3.4$\mathrm{MeV}$ alpha particle and a $14-\mathrm{MeV}$ neutron.
The neutron would be used to breed ${ }^{233} \mathrm{U}$ from $\mathrm{Th}$ in the fusion blanket. Each fusion neutron would breed about one ${ }^{233} \mathrm{U}$ and one T. Like ${ }^{235} \mathrm{U},{ }^{233} \mathrm{U}$ generates about $200 \mathrm{MeV}$ when it fissions. Fission is energy rich and neutron poor, whereas fusion is energy poor and neutron rich. A single fusion breeder could support perhaps 10 satellite burners, whereas a fission breeder supports perhaps one. A related concept is the particle accelerator-fission hybrid breeder (56): Thirty $3-\mathrm{MeV}$ neutrons result from each $1000-\mathrm{MeV}$ proton accelerated into molten lead; upon injection to a subcritical reactor, these could increase reactivity enough to breed ${ }^{233} \mathrm{U}$ from Th, provide electricity, and power the accelerator efficiently ( $\sim 10 \%$ of the output). The radiotoxicity of hybrid breeder reactors over time is expected to be substantially below LWRs.

These ideas appear important enough to pursue experimentally, but both fission and fusion are unlikely to play significant roles in climate stabilization without aggressive research and, in the case of fission, without the resolution of outstanding issues of high-level waste disposal and weapons proliferation.

\section{Geoengineering}

No discussion of global warming mitigation is complete without mentioning "geoengineering" $(78,79)$, also called climate engineering or planetary engineering on Earth and terraforming on other planets (80). Geoengineering in the climate change context refers mainly to altering the planetary radiation balance to affect climate and uses technologies to compensate for the inadvertent global warming produced by fossil fuel $\mathrm{CO}_{2}$ and other greenhouse gases. An early idea was to put layers of reflective sulfate aerosol in the upper atmosphere to counteract greenhouse warming (81). Variations on the sunblocking theme include injecting sub-micrometer dust to the stratosphere in shells fired by naval guns, increasing cloud cover by seeding, and shadowing Earth by objects in space (82). Perhaps most ambitious is a proposed 2000$\mathrm{km}$-diameter mirror of $10-\mu \mathrm{m}$ glass fabricated from lunar materials at the $\mathrm{L}_{1}(83) \mathrm{La}-$ grange point of the Sun-Earth system (84) (Fig. 3C). The mirror's surface would look like a permanent sunspot, would deflect $2 \%$ of solar flux, and would roughly compensate for the radiative forcing of a $\mathrm{CO}_{2}$ doubling. Climate model runs indicate that the spatial pattern of climate would resemble that without fossil fuel $\mathrm{CO}_{2}$ (84). Engineering the optical properties of aerosols injected to the stratosphere to produce a variety of climatic effects has also been proposed (85). Our assessment reveals major challenges to stabilizing the fossil fuel greenhouse with energy technology transformations. It is only prudent to pursue geoengineering research as an in- surance policy should global warming impacts prove worse than anticipated and other measures fail or prove too costly. Of course, large-scale geophysical interventions are inherently risky and need to be approached with caution.

\section{Concluding Remarks}

Even as evidence for global warming accumulates, the dependence of civilization on the oxidation of coal, oil, and gas for energy makes an appropriate response difficult. The disparity between what is needed and what can be done without great compromise may become more acute as the global economy grows and as larger reductions in $\mathrm{CO}_{2}$-emitting energy relative to growing total energy demand are required. Energy is critical to global prosperity and equity.

If Earth continues to warm, people may turn to advanced technologies for solutions. Combating global warming by radical restructuring of the global energy system could be the technology challenge of the century. We have identified a portfolio of promising technologies here-some radical departures from our present fossil fuel system. Many concepts will fail, and staying the course will require leadership. Stabilizing climate is not easy. At the very least, it requires political will, targeted research and development, and international cooperation. Most of all, it requires the recognition that, although regulation can play a role, the fossil fuel greenhouse effect is an energy problem that cannot be simply regulated away.

\section{References and Notes}

1. S. Arrhenius, Phila. Mag. 41, 237 (1896).

2. J. R. McNeill, Something New Under the Sun: An Environmental History of the Twentieth Century (Norton, New York, 2000).

3. J. T. Houghton et al., Eds., Climate Change 2001: Scientific Basis (Cambridge Univ. Press, New York, 2001).

4. M. I. Hoffert, C. Covey, Nature 360, 573 (1992).

5. United Nations Framework Convention on Climate Change, Text of the Convention, May 1992, Rio de Janeiro, Brazil (United Nations Environment Program-World Meteorological Organization, Climate Change Secretariat, Geneva, 1992).

6. B. C. O'Neill, M. Oppenheimer, Science 296, 1971 (2002).

7. T. M. L. Wigley, R. Richels, J. A. Edmonds. Nature $\mathbf{3 7 9}$ 240 (1996)

8. M. I. Hoffert et al., Nature 395, 881 (1998).

9. B. Bolin, H. S. Kheshgi, Proc. Natl. Acad. Sci. U.S.A. 98, 4850 (2001).

10. J. Hansen, M. Sato, R. Ruedy, A, Lacis, V. Oinas, Proc. Natl. Acad. Sci. U.S.A. 97, 9875 (2000).

11. R. B. Cheney et al., National Energy Policy: Report of the National Energy Policy Development Group (The White House, Washington, DC, May 2001); available at www.whitehouse.gov/energy/National-EnergyPolicy.pdf.

12. B. Metz et al., Eds., Climate Change 2001: Mitigation (Cambridge Univ. Press, New York, 2001), p. 8.

13. National Laboratory Directors, Technology Opportunities to Reduce U.S. Greenhouse Gas Emissions (DOE, Washington, DC, 1997); available at www.ornl.gov/ climate_change/climate.htm.

14. M. I. Hoffert, S. E. Potter, in Engineering Response to 


\section{SCIENCE'S COMPASS}

Global Climate Change, R. G. Watts, Ed. (Lewis, Boca Raton, FL, 1997), pp. 205-259.

15. V. Smil, Energies (MIT Press, Cambridge, MA, 1999).

16. J. H. Ausubel, C. Marchetti, Daedalus 125, 139 (1996)

17. A. H. Rosenfield, T. M. Kaarsberg, J. Romm, Phys. Today, 53, 29 (November 2000).

18. M. A. Weiss, J. B. Heywood, E. M. Drake, A. Schafer, F. F. AuYeung, On the Road in 2020: A Life-Cycle Analysis of New Automobile Technologies, EL 00-003 (MIT Energy Laboratory, Cambridge, MA, 2000); available at web.mit.edu/energylab/www/pubs/el00003.pdf.

19. K. H. Hellman, R. M. Heavenrich, Light-Duty Automotive Technology and Fuel Economy Trends: 1975 Through 2001, EPA420-R-01-008 (U.S. Environmental Protection Agency, Washington, DC, 2001); available at www.epa.gov/OMS/cert/mpg/fetrends/ r01008.pdf.

20. C. Marchetti, Nucl. Sci. Eng. 90, 521 (1985)

21. C.-J. Winter, J. Nitsch, Eds., Hydrogen as an EnergyCarrier (Springer-Verlag, New York, 1988)

22. N. Nakićenović, A. Grübler, A. McDonald, Global Energy Perspectives (Cambridge Univ. Press, New York, 1998), p. 52.

23. Energy in recoverable fossil fuels ("reserves" plus "resources" from conventional and unconventional sources) is $\sim 4800$ TW-year for coal and $\sim 1200$ TW-year each for oil and gas [converted from values in (22); 1 billion metric ton oil equivalent $=44.8 \mathrm{EJ}=$ 1.42 TW-year; natural gas includes liquids, excludes methane hydrates]. Total energy in recoverable fossil fuels ranges from 6400 to 8000 TW-year, two-thirds of which is coal. Coal resources could roughly double if energy in shales could be extracted cost-effectively.

24. J. P. Holdren et al., Federal Energy Research and Development for the Challenges of the Twenty-First Century (President's Committee of Advisors on Science and Technology [PCAST], Washington, DC, 1997); available at www.ostp.gov/Energy/index.html.

25. D. Reichle et al., Carbon Sequestration Research and Development (DOE, Washington, DC, 1999); available at www.ornl.gov/carbon sequestration/.

26. P. M. Cox, R. A. Betts, C. D. Jones, S. A. Spall, I. J. Totterdell, Nature 408, 184 (2000).

27. J. E. Martin, S. E. Fitzwater, R. M. Gordon, Glob. Biogeochem. Cycles 4, 5 (1990).

28. F. J. Dyson, G. Marland, Workshop on the Global Effects of Carbon Dioxide from Fossil Fuels, Report CONF-770385 (DOE, Washington, DC, 1977), pp. 111-118.

29. R. A. Metzger, G. Benford, Clim. Change 49, 11 (2001).

30. K. S. Lackner, P. Grimes, H.-J. Ziock, Carbon Dioxide Extraction from Air: Is It an Option? Technical Report LA-UR-99-583 (Los Alamos National Laboratory, Los Alamos, NM, 1999); available at www.lanl.gov/ energy/ecology/carbon/docs/AirExtraction.pdf.

31. H. Herzog, B. Eliasson, O. Kaarstad, Sci. Am. 282, 72 (2000).

32. H. S. Kheshgi, B. P. Flannery, M. I. Hoffert, A. G. Lapenis, Energy 19, 967 (1994).

33. K. Caldeira, G. H. Rau, Geophys. Res. Lett. 27, 225 (2000).

34. Carbon dioxide dissolves in water and slowly corrodes carbonate sediment, resulting in the storage of fossil fuel carbon primarily as bicarbonate ions dissolved in the ocean. Left to nature, the net reaction $\mathrm{CO}_{2}+\mathrm{H}_{2} \mathrm{O}+\mathrm{CaCO}_{3} \rightarrow \mathrm{Ca}^{2+}+\mathrm{HCO}_{3}^{-}$would occur on the time scale of $\sim 6000$ years.

35. K. S. Lackner, C. H. Wendt, D. P. Butt, E. L. Joyce Jr., D. H. Sharp, Energy 20, 1153 (1995).

36. T. B. Johansson, H. Kelly, A. K. N. Reddy, R. H. Williams, Eds., Renewable Energy (Island Press, Washington, DC, 1993).
37. H. S. Kheshgi, R. C. Prince, G. Marland, Annu. Rev. Energy Environ. 25, 199 (2000).

38. J. A. Turner, Science 285, 687 (1999).

39. H. C. Hayden, The Solar Fraud: Why Solar Energy Won't Run the World (Vales Lake Publishing, Pueblo West, CO, 2001), p. 161.

40. J. K. Strickland Jr., Sol. Energy 56, 23 (1996)

41. B. C. H. Steele, A. Heinzel, Nature 414, 345 (2001).

42. J. G. Bednorz, K. A. Müller, Z. Phys. B 64, 189 (1986).

43. R. B. Fuller, Critical Path (St. Martins, New York, 1981).

44. P. E. Glaser, Science 162, 857 (1968).

45. F. P. Davidson, K. I. Csigi, Eds., Solar Power Satellites (Wiley-Praxis, New York, 1997).

46. J. Mankins, Aerosp. Am. 35, 30 (1997).

47. M. I. Hoffert, S. D. Potter, in Solar Power Satellites, P. E. Glaser, F. P. Davidson, K. I. Csigi, Eds. (WileyPraxis, New York, 1997), pp. 231-254.

48. D. R. Criswell, in Innovative Solutions to $\mathrm{CO}_{2}$ Stabilization, R. Watts, Ed. (Cambridge Univ. Press, New York, 2002), pp. 345-410.

49. , Ind. Physicist 8, 12 (April/May 2002).

50. G. A. Landis, in Proceedings of Solar Power Satellite '97 Conference, 24 to 28 August 1997, Montreal, Canada (Canadian Aeronautics and Space Institute, Ottawa, Canada, 1997), pp. 327-328.

51. M. Nagatomo, Sol. Energy 56, 111 (1996).

52. P. Collins, Y. Purwanto, X. C. Ji, Space Energy Transp. 4, 47 (1999)

53. Committee for the Assessment of NASA's Space Solar Power Investment Strategy, Aeronautics and Space Engineering Board, National Research Council, Laying the Foundation for Space Solar Power: An Assessment of NASA's Space Solar Power Investment Strategy (National Academy Press, Washington, DC, 2001).

54. S. J. Smith, N. Mahasenan, J. F. Clarke, J. Edmonds, Space Solar Electric Power: Future Market Share Under Competition (Battelle Memorial Institute, Washington, DC, 2001).

55. H. G. Graetzer, Am. J. Phys. 32, 10 (1964) [translation from O. Hahn, F. Strassmann, Naturwissenschaften 27, 11 (1939)].

56. A. M. Weinberg, in Technologies for a GreenhouseConstrained Society, M. A. Kuliasha, A. Zuker, K. J. Ballew, Eds. (Lewis, Boca Raton, FL, 1992), Pp. 227237.

57. R. L. Garwin, G. Charpak, Megawatts and Megatons: A Turning Point in the Nuclear Age (Knopf, New York, 2001).

58. W. C. Sailor, D. Bodansky, C. Braun, S. Fetter, B. van der Zwaan, Science 288, 1177 (2000).

59. M. A. Adelman, J. C. Houghton, G. Kaufman, M. B. Zimmerman, Energy Resources in an Uncertain Future (Ballinger, Cambridge, MA, 1983), p. 334

60. Fission energy per ton $\left(\mathrm{J} \mathrm{t}^{-1}\right)^{235} \mathrm{U}$ is $\frac{202 \mathrm{MeV}}{235 \mathrm{amu} \times 1.661 \times 10^{-27} \mathrm{~kg} / \mathrm{amu}} \times$

$$
\frac{1.602 \times 10^{-13} \mathrm{~J}}{1 \mathrm{MeV}} \times \frac{10^{3} \mathrm{~kg}}{1 \mathrm{ton}}=8.3 \times 10^{16} \frac{\mathrm{J}}{\mathrm{t}^{235} \mathrm{U}}
$$

The ${ }^{235} \mathrm{U}$ energy per ton natural $U$ is therefore $0.0072 \times 8.3 \times 10^{16} \mathrm{Jt}^{-1} \approx 6 \times 10^{14} \mathrm{Jt}^{-1}$, and the energy in proven $U$ reserves and ultimately recoverable resources is $\sim 61$ and 300 TW-year, respectively $(1 \mathrm{TW}$-year $=31.5 \mathrm{EJ})$.

61. S. Nakamura, K. Oguma, Y. Ito, J. Chem. Eng. Jpn. 28, 660 (1995).

62. P. Henderson, Inorganic Geochemistry (Pergamon, New York, 1982), p. 282.

63. J. P. Peixoto, A. H. Oort, Physics of Climate (American Institute of Physics, New York, 1992), p. 271.

64. The flow rate through a hypothetical seawater extraction plant to yield ${ }^{235} \mathrm{U}$ fuel at $10 \mathrm{TW}$ is

$$
\begin{aligned}
10 \mathrm{TW} & \times \frac{1.37 \times 10^{18} \mathrm{~m}^{3}}{8 \times 10^{4} \mathrm{TW}-\mathrm{year}} \times \\
& \frac{1 \text { year }}{3.15 \times 10^{7} \mathrm{~s}}=5.4 \times 10^{6} \mathrm{~m}^{3} \mathrm{~s}^{-1} .
\end{aligned}
$$

65. T. K. Fowler, The Fusion Quest (Johns Hopkins, Baltimore, MD, 1997).

66. J. D. Lawson, Proc. Phys. Soc. London B 70, 6 (1957).

67. G. H. Miley, Fusion Energy Conversion (American Nuclear Society, LaGrange Park, IL, 1976).

68. W. Manheimer, Fusion Technol. 36, 1 (1999).

69. L. M. Lidsky, in Energy Technology Handbook, D. M. Considine, Ed. (McGraw-Hill, New York, 1977), pp. 5-134.

70. G. L. Kulcinski, J. F. Santarius, Nature 396, 724 (1998).

71. J. Kesner, L. Bromberg, M. Mauel, D. Garnier, J. M. Dawson, The Dipole Fusion Confinement Concept: A White Paper for the Fusion Community (MIT Plasma Science and Fusion Center, Cambridge, MA, 1998); available at www.psfc.mit.edu/ldx/pubs/dipole wp.pdf.

72. L. J. Wittenberg, J. F. Santarius, G. L. Kulcinski, Fusion Technol. 10, 167 (1987)

73. J. S. Lewis, Space Power 10, 363 (1991).

74. Fusion Energy Sciences Act of 2001, H.R. 1781 (107th Congress).

75. ${ }^{239} \mathrm{Pu}$ and ${ }^{233} \mathrm{U}$ don't exist in nature. They must be bred from their feedstocks, $238 \mathrm{U}(\sim 99 \%$ of $U)$ and ${ }^{232}$ Th ( $\sim 100 \%$ of thorium), with the use of suitable neutron sources ${ }^{238} \mathrm{U}+\mathrm{n} \rightarrow{ }^{239} \mathrm{Pu} ;{ }^{232} \mathrm{Th}+\mathrm{n} \rightarrow$ $\left.{ }^{233} \mathrm{U}\right)$. Fission energy per unit mass is comparable to ${ }^{235} \mathrm{U}\left({ }^{239} \mathrm{Pu}+\mathrm{n} \rightarrow\right.$ fission products $+2.9 \mathrm{n}+210$ $\mathrm{MeV} ;{ }^{233} \mathrm{U}+\mathrm{n} \rightarrow$ fission products $+2.5 \mathrm{n}+198$ $\mathrm{MeV})$. We estimate breeding could increase fission energy resources by factors of 60 and 180 for ${ }^{239} \mathrm{Pu}$ and ${ }^{233} \mathrm{U}$, respectively. Breeding rates depend on feedstock mining rates and availability of neutrons.

76. Committee on Separations Technology and Transmutation Systems, Board on Radioactive Waste Management, Commission on Geosciences, Environment, and Resources, National Research Council, Nuclear Wastes: Technologies for Separations and Transmutations (National Academy Press, Washington, DC, 1996).

77. H. Bethe, Phys. Today 32, 45 (May 1979)

78. S. H. Schneider, Nature 409, 417 (2001)

79. D. W. Keith, Nature 409, 420 (2001).

80. M. J. Fogg, Terraforming: Engineering Planetary Environments (Society of Automotive Engineers International, Warrendale, PA, 1995).

81. M. I. Budyko, Climate Changes, R. Zolina, Transl., L Levin, Ed. (American Geophysical Union, Washington DC, 1977).

82. Panel on Policy Implications of Greenhouse Warming Committee on Science, Engineering, and Public Policy, National Academy of Sciences, National Academy of Engineering, Institute of Medicine, Policy Implications of Greenhouse Warming: Mitigation, Adaptation and the Science Base (National Academy Press, Washington, DC, 1992), pp. 433-464.

83. J. T. Early, J. Br. Interplanet. Soc. 42, 567 (1989).

84. B. Govindasamy, K. Caldeira, Geophys. Res. Lett. 27 2141 (2000).

85. E. Teller, L. Wood, R. Hyde, Global Warming and Ice Ages: Prospects for Physics-Based Modulation of Global Change, Report UCRL-231636/UCRL JC 128715 (Lawrence Livermore National Laboratory, Livermore, CA, 1997).

86. We thank D. Harvey, J. Katzenberger, M. MacCracken, G. Marland, J. Palfreman, V. Smil, and P. Werbos for valuable discussions. K.C, H.H., and A.K.J. thank the DOE-Office of Biological and Environmental Research for support in this work. 